\title{
TEMPORARY COMMUNAL BROODING IN NORTHERN BOBWHITE AND SCALED QUAIL BROODS
}

\author{
Jeremy P. Orange ${ }^{1,2}$, Craig A. Davis ${ }^{1}$, R. Dwayne Elmore ${ }^{1}$, and Samuel D. Fuhlendorf ${ }^{1}$
}

\begin{abstract}
Communal brooding, which can occur as a result of brood amalgamation or communal parental care, is a common alternative brooding strategy observed in many precocial bird species. Although the occurrence of long-term communal brooding has been documented in numerous waterfowl species, and to a lesser extent in gallinaceous species, the occurrence and mechanisms facilitating temporary or short-term communal broods is less understood. During the 2013 and 2014 breeding seasons, we anecdotally observed temporary communal brooding in 3 Northern Bobwhite (Colinus virginianus) broods and one Scaled Quail (Callipepla squamata) brood. We present 3 mechanisms that may explain the occurrences of temporary communal brooding: (1) cool weather conditions observed at intermittent intervals throughout the breeding season, (2) predator avoidance behavior, and (3) a random proximity mechanism that triggers communal brooding in these highly gregarious bird species. It is our hope that these observations will facilitate future research investigating the impact that temporary communal brooding may have on survival and recruitment of gallinaceous birds.
\end{abstract}

RESUMEN.-La crianza comunal, la cual puede ocurrir como resultado de la amalgamación de las puestas, o el cuidado parental comunal, es una estrategia de crianza alternativa común en muchas especies de aves precociales. Aunque la aparición de largos períodos de crianza comunal se ha documentado en numerosas especies de aves acuáticas y, en menor medida, en especies gallináceas, los casos y mecanismos que facilitan la crianza comunal temporal o de corto plazo han sido poco estudiados. Durante la época de crianza del 2013 y 2014, observamos de manera anecdótica crianza comunal temporal en 3 nidadas de codornices norteñas (Colinus virginianus) y 1 nidada de codorniz escamosa (Callipepla squamata). Presentamos 3 mecanismos que pueden explicar las apariciones de crianza comunal temporal, incluyendo el resultado de condiciones climáticas de frío observadas en intervalos intermitentes a lo largo de la temporada de crianza, una conducta de evasión de depredadores, y un mecanismo de proximidad al azar que desencadena nidadas comunales en estas especies de aves altamente gregarias. Esperamos que estas observaciones faciliten futuras investigaciones que investiguen qué impacto puede tener la crianza comunal temporal en la supervivencia y el reclutamiento de las gallináceas.

Brood amalgamation is a common broodrearing strategy that has been documented in numerous gallinaceous and waterfowl species (Mills and Rumble 1991, Lott and Mastrup 1999, Brooks and Rollins 2007, Wong et al. 2009, Dahlgren et al. 2010). These amalgamations can occur in 4 forms including kidnapping, adoption, crèching, and gang-brooding (Eadie et al. 1988, Afton and Paulus 1993, Faircloth et al. 2005, Brooks and Rollins 2007). Amalgamations of particular interest in this study are gang-brooding and crèching, which are also known as communal brooding. Gangbrooding occurs when 2 or more adults combine their respective broods into one group, and crèching occurs when 2 or more unrelated chicks are cared for by 2 or more adults that may or may not be related to them (Eadie et al. 1988, Afton and Paulus 1993, Faircloth et al. 2005, Brooks and Rollins 2007). Communal brooding has been documented in numerous gallinaceous species, including Northern Bobwhite (Colinus virginianus; Faircloth et al. 2005, Brooks and Rollins 2007), California Quail (Callipepla californica; Lott and Mastrup 1999, Calkins 2007), Gambel's Quail (C. gambelii; Brown et al. 1998), Rio Grande Wild Turkey (Meleagris gallopavo intermedia; Spears et al. 2005), Ocellated Turkey (Meleagris ocellata; Gonzalez et al. 1998), and several grouse species (Wing et al. 1944).

Communal broods can be as temporary as a few minutes or as long as an entire brooding period (Boos et al. 1989, Brooks and Rollins 2007), and numerous theories have been presented to explain the short- and long-term occurrences of this breeding strategy. In California Quail, brooding adults engaged in longterm communal brooding, thereby increasing survival by reducing the time individuals

\footnotetext{
${ }^{1}$ Department of Natural Resource Ecology and Management, Oklahoma State University, Stillwater, OK 74078.

2E-mail: jporange2@gmail.com
} 
spent being vigilant, which allowed adults to allocate more time to feeding and individual care (Lott and Mastrup 1999). In bobwhites, it is believed that long-term communal brooding in the form of gang-brooding increases reproductive flexibility (Brooks and Rollins 2007) and bobwhite hens have been documented abandoning chicks to begin a new nest (Curtis et al. 1993, Burger et al. 1995b, Suchy and Munkel 2000).

Although long-term communal brooding has been documented in numerous gallinaceous species, little is known about temporary communal brooding in this order of birds. For the purposes of this study, we define temporary communal brooding as the occurrence of short-term gang-brooding, crèching, or communal parental care that is nonpermanent and is followed by brood separation. Although, little is known regarding temporary communal brooding in gallinaceous species, this brooding strategy has been anecdotally observed in waterfowl and shorebird species including Mallards (Anas platyrhynchos; Boos et al. 1989), King Eider (Somateria spectabilis; Mehl et al. 2007), and Bristle-thighed Curlews (Numenius tahitiensis; Lanctot et al. 1995). In waterfowl and shorebird species, temporary communal brooding has been hypothesized to occur as a mechanism to guard against predation (Boos et al. 1989, Lanctot et al. 1995), or as part of a strategy to search out better brooding territories (Mehl et al. 2007).

Throughout their distributions, many gallinaceous species, including quail, are suffering from severe and long-term population declines (Sauer et al. 2014). In order to effectively manage these species, it is important for managers to have a thorough understanding of species-specific breeding and brooding ecology. Temporary communal brooding has the potential to significantly affect chick survival and recruitment in quail and other gallinaceous species, and currently little is known about this alternative brooding strategy. Here, we document occurrences of temporary communal brooding in Northern Bobwhite (hereafter "bobwhite") and Scaled Quail (Callipepla squamata) in western Oklahoma, and postulate 3 mechanisms that may have facilitated this alternative brooding strategy.

As part of a companion research project investigating chick survival and reproductive behavior, adult bobwhite and Scaled Quail were captured at Beaver River Wildlife Management Area in western Oklahoma from 2012 to 2014. Adults were fitted with 7-g necklacestyle collars (Advanced Telemetry Solutions, Isanti, MN), and during the breeding season nests were located via radiotelemetry and checked daily. After chicks hatched, we radiotracked adults with broods daily. During daily tracking events, broods were located by homing (White and Garrott 1990) to a distance of 20-30 m to avoid disruption. When chicks reached an age of 8-12 d, they were captured during a nightly capture event with methods described by Smith et al. (2003) and Andes et al. (2012). Capture events typically occurred between the hours of 04:00 and 06:30. A FLIR Thermal Imaging Camera i $7^{\circledR}$ (FLIR Systems, Wilsonville, OR) was used for locating broods and capturing chicks. Following capture, we fitted chicks with a 0.45 -g suture-style transmitter (American Wildlife Enterprises, Monticello, FL). Transmitters had an expected battery life of 21-23 d and broods were tracked 6-7 d per week until we initiated a second capture when batteries were close to expiring. Weather data were collected using a WeatherHawk 232 (WeatherHawk, Logan, UT) weather station that was located on the study site.

During our study, we completed 44 successful capture events in which we captured chicks from 46 broods (27 bobwhite, 19 Scaled Quail). One brooding adult was present in 25 capture events, 2 brooding adults were present in 17 capture events, and 3 brooding adults were present in 2 capture events. Temporary communal brooding was observed during 4 capture events. The mean minimum nightly temperature for all capture events was $18.26{ }^{\circ} \mathrm{C}$ (SE 0.58). Precipitation occurred in the evening preceding capture or the morning of the capture event during 10 of $44(22.7 \%)$ capture events.

The first occurrence of temporary communal brooding occurred on 9 June 2014. Two radio-marked female Scaled Quail had been brooding their chicks in close proximity (within $100 \mathrm{~m}$ ) of each other during daytime radio-tracking events, but during the capture event, both broods were observed roosting together. During the capture event, we were able to capture 5 chicks, but it was probable that more chicks were present. All chicks were approximately 8-9 days old at time of capture. Following transmitter attachment, the broods 
remained together until 11 June. When the broods separated, one adult had one radiomarked chick, whereas the second adult had 4 of the radio-marked chicks and the broods did not rejoin thereafter. Nightly temperatures ranged from $11.3{ }^{\circ} \mathrm{C}$ to $12.7{ }^{\circ} \mathrm{C}$, and were approximately $4-5{ }^{\circ} \mathrm{C}$ lower than the average minimum nightly temperatures observed throughout June 2014. Approximately $8 \mathrm{~mm}$ of precipitation fell between 22:00 and 01:00 during the night preceding the capture event.

A second occurrence of temporary communal brooding occurred on 17 July 2014 . One radio-marked adult bobwhite male with 6 chicks approximately 8-9 days old was located roosting with an unmarked female brooding 9 chicks. Previous locations did not indicate that this brooding female was with the adult male because chicks captured with the hen were only 3-4 days old based upon their mass at capture (7.7-8.6 g). The 2 broods separated the following day, and the unmarked female and her brood were not observed with the brood on the following night when they were checked unobtrusively with the FLIR Thermal Imaging Camera. Temperatures during the night of capture were at a 3-week low of 13.9 ${ }^{\circ} \mathrm{C}$, approximately $4{ }^{\circ} \mathrm{C}$ lower than the average minimum nightly temperatures observed in July 2014. Approximately $3 \mathrm{~mm}$ of precipitation fell between 23:00 and 24:00 in the night preceding the capture event.

A third occurrence of communal brooding occurred on 28 September 2013. During the capture event, the female brooding adult bobwhite, with 5 chicks, was located roosting with 2 additional adult males. Chicks were approximately 8-9 days old at time of capture. These additional adults had not been observed with the brood during prior daily tracking events. Minimum temperature during the night of capture was $9.4{ }^{\circ} \mathrm{C}$, which was the coldest temperature observed during all capture events. Approximately $45 \mathrm{~mm}$ of precipitation fell between 19:00 and 02:00 in the night preceding the capture event. The additional 2 adults were not observed with the brood again during a subsequent daytime brood flush; however, loose covey formation was observed throughout the study area during this time period and it is possible, albeit unlikely, that the additional brooding males rejoined the brood on following days. With the temperate autumn and late nesting season that lasted until early October during the 2013 season, we did not begin to observe covey formation until mid- to late October.

The fourth occurrence of communal brooding occurred on 8 July 2014 . During the capture event, the brooding adult female bobwhite, with 7 chicks, was located roosting with an additional adult male and female. Chicks were approximately 8-9 days old at time of capture. These additional adults had not been observed with the brood previously, and they were not observed with the brood during future monitoring and capture events. In fact, the brooding female later abandoned this brood when the chicks were approximately 25-28 days old, and chicks were later observed within a large unattended gang-brood. Minimum temperature during the night of capture was $20.1{ }^{\circ} \mathrm{C}$. Although the final 2 reported occurrences of temporary communal brooding may not precisely fall under the conventional designation of gang-brooding or crèching, these 2 occurrences are still a form of cooperative or communal brooding because the additional adults provide some form of care, albeit temporarily, to roosting chicks.

During the 2013 and 2014 breeding seasons, we observed temporary communal brooding during 4 capture events. In total, we observed temporary communal brooding in $16 \%$ of all of the capture events with a single brooding adult. Although we cannot conclusively prove that these occasions occurred as a result of a specific trigger, 3 plausible explanations exist to explain the occurrences of this alternative brooding strategy: (1) a response to atypically cold temperatures observed intermittently throughout the breeding season, (2) a behavioral adaptation to increase vigilance and reduce vulnerability to predation, and (3) a random proximity mechanism that facilitates communal brooding in these highly gregarious species.

One of the most plausible explanations for the observed occurrences of temporary communal brooding is a response to atypically cool temperatures. As with most precocial species, bobwhite and Scaled Quail chicks leave the nest hours after hatching and immediately become exposed to their environment. Small body mass and juvenile plumage leave quail chicks vulnerable to atypical fluctuations in temperature and thermal extremes (Spiers et al. 1985). As a result, chicks are dependent on the brooding adult throughout the day, 
but especially during the night, for thermal protection, as chicks are unable to independently thermoregulate until reaching an age of 30 days (Borchelt and Ringer 1973). Cool temperatures can lead to reductions in growth rates in quail chicks (Krijgsveld et al. 2003), as well as negative impacts on chick survival. Exposure to cold weather and precipitation has been observed to negatively impact chick survival and recruitment in Ring-necked Pheasants (Phasianus colchicus; Hill 1985, Riley et al. 1998) and Wild Turkeys (Meleagris gallopavo; Healy and Nenno 1985, Healy 1992). In addition to the effect of temperature on chicks, cool temperatures can also negatively impact brooding adults. Brooding is energetically costly to adults, especially during periods of cool temperatures and acute thermal stress (Pearson 1994). For example, brooding King Quail (Coturnix chinensis) hens have higher energetic demands than nonbrooding adults during periods of low temperatures (Pearson 1994).

Three of the 4 occurrences of communal brooding in our study were observed on atypically cool nights with precipitation, and these cool temperatures may have facilitated the temporary communal brooding observed. In fact, we observed temporary communal brooding, in 3 of the 5 capture events with the lowest nightly temperatures. Furthermore, precipitation occurred in 3 of the 4 occurrences of temporary communal brooding, and the wet conditions would have made chicks even more susceptible to cool temperatures. Although gregarious adults throughout the nonbreeding season gain thermoregulatory benefits from communal roosting in coveys, this roosting strategy can only be achieved during the breeding stage through biparental care or communal brood rearing. Biparental care was commonly observed in both bobwhite and Scaled Quail; however, the 4 broods in which we observed communal brooding had been brooding independently, without the assistance of a secondary brooding adult, until the date of capture. It is possible that broods with only one brooding adult are more vulnerable to atypically cool temperatures than are broods with 2 brooding adults. When chicks are young and temperatures become atypically cold, brooding adults may be forming temporary communal broods with individuals located in close proximity in an effort to increase chick survival and reduce energetic demands.

A second potential mechanism that may explain the observed occurrences of temporary communal brooding during our study is a behavioral response to predation. Bobwhite and Scaled Quail adults are vulnerable to high levels of predation risk (Rollins and Carroll 2001, Cox et al. 2004, Lusk et al. 2005), especially during brood rearing (Burger et al. 1995a). Furthermore, chicks face high mortality rates in the initial stages of their lives (DeMaso et al. 1997, Lusk et al. 2005). At 8-9 days old, chicks are incapable of flight, making them especially vulnerable to predation. In order to reduce vulnerability to predation, adults may form temporary communal broods to increase vigilance, and thus predator detection, while roosting. In Mallards (A. platyrhynchos), temporary communal broods lasted as little as $\mathbf{1 5}$ min, serving as a mechanism for predator protection (Boos et al. 1989). Similarly, adult Bristle-thighed Curlews (Numenius tahitiensis) have been hypothesized to engage in temporary communal brooding in order to increase vigilance and avoid predation (Lanctot et al. 1995). The increased vigilance of having 2 or more brooding adults, and their chicks, may potentially allow adults to more effectively detect predators. Furthermore, the addition of a second brood with chicks of an equal or lesser age may dilute the possibility that an adult's brood will be targeted during a predation event. Nonbrooding adults that communally roost with a brooding adult may also experience a lower probability of predation because predators may be more likely to target vulnerable chicks.

Finally, we postulate that the observed occurrences of temporary communal brooding are a random proximity mechanism that triggers communal brooding. Bobwhite and Scaled Quail are highly gregarious species, forming coveys in the fall and winter. In one of the 4 occurrences of temporary communal brooding, radio-tagged brooding adults were observed brooding in close proximity, which may have facilitated the formation of communal broods. Furthermore, all 4 occurrences of communal brooding occurred in areas in which we anecdotally observed some of the highest population densities within our study area. It is likely that as highly gregarious species, bobwhite and Scaled Quail may instinctually and randomly 
form temporary communal broods with individuals located in close proximity.

On the basis of our observations, we postulate that temporary communal brooding in bobwhite and Scaled Quail is likely a response to atypically cool temperature, but other factors such as vulnerability to predation and random occurrence may also play a role. Moreover, these factors may interactively facilitate the formation of temporary communal broods. Future research should investigate temporary communal brooding along with the impact that this alternative brooding strategy may have on chick and adult survival. Due to the intermittent occurrence of this alternative brooding strategy, and the prohibitive cost of miniature radio transmitters, it may be necessary to utilize a more direct or manipulative approach to further investigate temporary communal brooding.

Funding was provided by the PittmanRobertson Federal Aid to Wildlife Restoration Act under project W-161-R (F11AF00069) of the Oklahoma Department of Wildlife Conservation and Oklahoma State University, administered through the Oklahoma Cooperative Fish and Wildlife Research Unit (cooperating institutions: Oklahoma Department of Wildlife Conservation, Oklahoma State University, U.S. Geological Survey, U.S. Fish and Wildlife Service, and Wildlife Management Institute). We thank John Groendyke for providing the Groendyke Graduate Fellowship. Additionally, we thank Dr. David M. Leslie Jr. and Evan Tanner for their assistance with this project. Capture and handling protocols were approved by Oklahoma State University's Institutional Animal Care and Use Committee (ACUP \#AG132 and ACUP \#AG11-22).

\section{Literature Cited}

Afton, A.D., AND S.L. Paulus. 1993. Incubation and brood care. Pages 62-108 in B.D. Batt, A.D. Afton, M.G. Anderson, C.D. Ankney, D.H. Johnson, J.A. Kadlec, and G.L. Krapu, editors, Ecology and management of breeding waterfowl. University of Minnesota Press, Minneapolis, MN.

Andes, A.K., B.R. Buckley, T.L. Warren, P.C. Woods, S.R. YANCEY, and C.B. DABbert. 2012. Use of a thermal camera to aid in capturing northern bobwhite quail chicks. Wildlife Society Bulletin 36: 371-375.

Boos, J.D., T.D. Nudds, AND K. SJoberg. 1989. Posthatch brood amalgamation by mallards. Wilson Bulletin 101:503-505.
Borchelt, P., And R.K. Ringer. 1973. Temperature regulation development in bobwhite quail (Colinus virginianus). Poultry Science 52:793-798.

BRoOKs, J.L., AND D. Rollins. 2007. Gang-brooding in Northern Bobwhites in West Texas. Wilson Journal of Ornithology 119:137-138.

Brown, D.E., J.C. Hagelin, M. Taylor, and J. GalLOWAY. 1998. Gambel's Quail (Callipepla gambelii). The Birds of North America. Number 321.

Burger, L.W., T.V. Dailey, E.W. Kurzejeski, and M.R. RYAN. 1995a. Survival and cause-specific mortality of Northern Bobwhites in northern Missouri. Journal of Wildlife Management 59:401-410.

Burger, L.W., M.R. Ryan, T.V. Dailey, and E.W. KurzeJESKI. 1995b. Reproductive strategies, success, and mating systems of Northern Bobwhite in Missouri. Journal of Wildlife Management 59:417-426.

Calkins, J.D. 2007. The family behavior of California Quail: a molecular analysis. Condor 109:962-967.

Cox, S.A., A.D. Peoples, S.J. DeMaso, J.J. Lusk, F.S. GUTHERY. 2004. Survival and cause-specific mortality of Northern Bobwhites in western Oklahoma. Journal of Wildlife Management 68:663-671.

Curtis, P.D., B.S. Mueller, P.D. DoerR, C.F. Robinette, AND T. DEVos. 1993. Potential polygamous breeding behavior in Northern Bobwhite. Proceedings of the National Quail Symposium 3:55-63.

Dahlgren, D.K., T.A. Messmer, and D.N. Koons. 2010. Achieving better estimates of Greater Sage-Grouse chick survival in Utah. Journal of Wildlife Management 74:1286-1294.

DeMaso, S.J., A.D. Peoples, S.A. Cox, and E.S. Parky. 1997. Survival of Northern Bobwhite chicks in western Oklahoma. Journal of Wildlife Management 61: 846-853.

Eadie, J., F.P. Kehoe, and T.D. Nudds. 1988. Pre-hatch and post-hatch brood amalgamation in North American Anatidae: a review of hypotheses. Canadian Journal of Zoology 66:1709-1721.

Faircloth, B.C., W.E. Palmer, and J.P. Carroll. 2005. Post-hatching brood amalgamation in Northern Bobwhites. Journal of Field Ornithology 76:175-182.

Gonzalez, M.J., H.B. Quigley, and C.I. Taylor. 1998. Habitat use and reproductive ecology of the Ocellated Turkey in Tikal National Park, Guatemala. Wilson Bulletin 110:505-510.

Healy, W.M. 1992. Population influences: environment. Pages 129-143 in J.G. Dickson, editor, The Wild Turkey: biology and management. Stackpole Books, Harrisburg, PA.

Healy, W.M., and E.S. Nenno. 1985. Effect of weather on Wild Turkey poult survival. Proceedings of the National Wild Turkey Symposium 5:91-101.

HiLl, D.A. 1985. The feeding ecology and survival of pheasant chicks on arable farmland. Journal of Applied Ecology 22:645-654.

Krijgsveld, K.L., G.H. Visser, and S. DaAn. 2003. Foraging behavior and physiological changes in precocial quail chicks in response to low temperatures. Physiology and Behavior 79:311-319.

Lanctot, R.B., R.E. Gill JR., T.L. Tibbitts, and C.M. HANDEL. 1995. Brood amalgamation in the Bristlethighed Curlew Numenius tahitiensis: process and function. Ibis 137:559-569.

LotT, D.F., AND S.N.K. Mastrup. 1999. Facultative communal brood rearing in California Quail. Condor 101: 678-681. 
Lusk, J.J., F.S. Guthery, S.A. Cox, S.J. Demaso, And A.D. PEoples. 2005. Survival and growth of Northern Bobwhite chicks in western Oklahoma. American Midland Naturalist 153:389-395.

Mehl K.R., R.T. Alisauskas, and A.E. Burger. 2007. King Eider (Somateria spectabilis) brood ecology: correlates of duckling survival. Auk 124:606-618.

Mills, T.R., AND M.A. Rumble. 1991. Poult adoption in Merriam's Wild Turkeys. Wilson Bulletin 103:137-139.

Pearson, J.T. 1994. Oxygen consumption rates of adults and chicks during brooding in King Quail (Coturnix chinensis). Journal of Comparative Physiology 164: $415-424$.

Riley, T.Z., W.R. Clark, E. Ewing, and P.A. Vohs. 1998. Survival of Ring-necked Pheasant chicks during brood rearing. Journal of Wildlife Management 62:36-44.

Rollins, D., AND J.P. CARROLL. 2001. Impacts of predation on Northern Bobwhite and Scaled Quail. Wildlife Society Bulletin 29:39-51.

Sauer, J., J. Hines, J. Fallon, D. Pardieck, D.J. Ziolkowski, AND W.A. Link. 2014. The North American Breeding Bird Survey, results and analysis 1966-2012. Version 02.19.2014. USGS Patuxent Wildlife Research Center, Laurel, MD.

Smith, M.D., A.D. Hammond, L.W. Burger JR., W.E. Palmer, A.V. Carver, and S.D. WellendorF. 2003.
A technique for capturing Northern Bobwhite chicks. Wildlife Society Bulletin 31:1054-1060.

Spears, B.L., W.B. Ballard, M.C. Wallace, R.S. Phillips, D.P. Holdstock, J.H. Brunjes, R.D. Applegate, M.S. Miller, AND P.S. GiPSON. 2005. Survival of Rio Grande turkey chicks. Journal of Field Ornithology 76:12-20.

Spiers, D.E., T. Adams, and R.K. Ringer. 1985. Homeothermic development in the bobwhite (Colinus virginianus). Comparative Biochemistry and Physiology 81:921-927.

Suchy, W.J., AND R.J. Munkel. 2000. Survival rates of Northern Bobwhite chicks in south-central Iowa. Proceedings of the National Quail Symposium 4:82-84.

White, G.C., and R.A. GarrotT. 1990. Analysis of wildlife radio-tracking data. Academic Press, New York, NY.

Wing, L., J. BeER, and W. Tidyman. 1944. Brood habits and growth of 'Blue Grouse.' Auk 61:426-440.

Wong, M.M.L., B.C. Fedy, S. Wilson, and K.M. Martin. 2009. Adoption in Rock and White-tailed Ptarmigan. Wilson Journal of Ornithology 121:638-641.

Received 1 October 2015 Accepted 1 December 2015 